\title{
Melanocortin receptors in rat liver cells: change of gene expression and intracellular localization during acute-phase response
}

\author{
Ihtzaz Ahmed Malik · Jakob Triebel $\cdot$ Jessica Posselt • \\ Sajjad Khan · Pierluigi Ramadori · Dirk Raddatz • \\ Giuliano Ramadori
}

Accepted: 29 November 2011 / Published online: 20 December 2011

(C) The Author(s) 2011. This article is published with open access at Springerlink.com

\begin{abstract}
MCRs are known to be expressed predominantly in the brain where they mediate metabolic and antiinflammatory functions. Leptin plays an important role in appetite and energy regulation via signaling through melanocortin receptors (MCRs) in the brain. As serum levels of MCR ligands are elevated in a clinical situation [acutephase response (APR)] to tissue damage, where the liver is responsible for the metabolic changes, we studied hepatic gene expression of MCRs in a model of muscle tissue damage induced by turpentine oil (TO) injection in rats. A significant increase in gene expression of all five MCRs (MC4R was the highest) in liver at the RNA and protein level was detected after TO injection. A similar pattern of increase was also found in the brain. Immunohistology showed MC4R in the cytoplasm, but also in the nucleus of parenchymal and non-parenchymal liver cells, whereas MC3R-positivity was mainly cytoplasmic. A time-dependent migration of $\mathrm{MC} 4 \mathrm{R}$ protein from the cytoplasm into
\end{abstract}

I. A. Malik and J. Triebel contributed equally to this work.

Electronic supplementary material The online version of this article (doi:10.1007/s00418-011-0899-7) contains supplementary material, which is available to authorized users.

I. A. Malik · J. Triebel · J. Posselt · S. Khan · P. Ramadori ·

D. Raddatz $\cdot$ G. Ramadori $(\bowtie)$

Division of Gastroenterology and Endocrinology,

Department of Internal Medicine, University Medical Center

Göttingen, Robert-Koch-Str. 40, 37075 Göttingen, Germany

e-mail: gramado@med.uni-goettingen.de

Present Address:

J. Triebel

Instituto de Neurobiología, Universidad Nacional Autónoma de

México (UNAM), Campus UNAM-Juriquilla,

Blvd. Juriquilla 3001, 76230 Querétaro, QRO, Mexico the nucleus was observed during APR, in parallel with an increase in $\alpha$-MSH and leptin serum levels. An increase of MC4R was detected at the protein level in wild-type mice, while such an increase was not observed in IL-6ko mice during APR. Moreover, treatment of isolated liver cells with melanocortin agonists ( $\alpha$-MSH and THIQ) inhibited the endotoxin-induced upregulation of the acute-phase cytokine (IL-6, IL1 $\beta$ and TNF- $\alpha$ ) gene expression in Kupffer cells and of chemokine gene expression in hepatocytes. MCRs are expressed not only in the brain, but also in liver cells and their gene expression in liver and brain tissue is upregulated during APR. Due to the presence of specific ligands in the serum, they may mediate metabolic changes and exert a protective effect on liver cells.

Keywords Melanocortin receptors · Cytokines - Liver . Brain · Acute-phase response

\section{Introduction}

The melanocortin system consists of several agonists, two antagonists and five receptors. The agonists, including $\alpha$-melanocyte-stimulating hormone $(\alpha$-MSH), $\beta$-MSH, $\gamma$-MSH and ACTH, are all derived from tissue-specific posttranslational processing of a pre-prohormone, pro-opiomelanocortin (POMC) (Butler 2006; Mountjoy et al. 1992). Five melanocortin receptors (MCRs) mediate the diverse actions of the melanocortins. They are numbered MC1R to MC5R according to the sequence of their cloning (Mountjoy et al. 1992). The melanocortin 4 receptor (MC4R), the fourth of five known receptor subtypes, is widely expressed in the central nervous system (Gantz and Fong 2003; Mountjoy et al. 1992; Tao 2010). The MC4R, as a part of the central melanocortin system, is also known for the mediation of 
orexigenic and anorexic signals in the control of appetite, food intake, body weight control and energy homeostasis (Gantz and Fong 2003). In fact, chronic central and peripheral administration of non-selective melanocortin receptor agonists reduces food consumption and causes weight loss. Experimental observations on MC4R-/- mice indicate an imbalance in fat consumption and oxidation compared to the respective wild-type strain, supporting the notion that this receptor plays a key role in the regulation of energy expenditure and fatty acid oxidation (Butler 2006).

Besides the melanocortin system, some other circulating hormones are thought to play an important role as modulators of energy flow within the organism. For example, the adipocyte-derived hormone leptin is involved in regulation of metabolic processes by acting on the brain (Vrang et al. 2002). In fact, a number of experiments have documented that circulating leptin enters the brain to interact with hypothalamic neurones regulating appetite and metabolism (Seeley et al. 1997; Vrang et al. 2002).

It has been reported that leptin is able to induce gene expression of pro-opiomelanocortin (POMC) in mouse brain (Vrang et al. 2002) and the role of arcuate POMC neurons as downstream mediators of leptin's effects upon energy homeostasis is also well recognized (Seeley et al. 1997). Moreover, pharmacological blockade of MC4R attenuates the ability of leptin to reduce food intake or body weight in rats (Seeley et al. 1997).

Leptin and melanocortin receptors are known to be abundantly expressed in brain (Seeley et al. 1997). Furthermore, leptin is thought to regulate hepatic and peripheral tissue glucose metabolism through interaction with the MCRs (Shimizu et al. 2007; Toda et al. 2009). Leptin receptors, however, are also found in the liver (Cohen et al. 2007) raising the possibility of a similar role there. Indeed, leptin has been attributed an important role in the regulation of fatty acid uptake in hepatocytes (Ge et al. 2010). In contrast to leptin receptors, MCRs have not been described in the liver.

Acute-phase response (APR) is the systemic reaction to tissue injury and inflammation. It is clinically characterized by systemic symptoms such as fever, weakness, adinamia, somnolence and loss of appetite. In the blood, leucocytosis, increased erythrocyte sedimentation rate, increased serum level of corticosteroids and dramatic changes in serum levels of acute-phase proteins (APP) represent the most striking features of APR (Ramadori and Christ 1999; Ramadori et al. 2008). Metabolic derangements in APR include increased resting energy expenditure and proteolysis, besides hyperglycemia associated with increased glucose production and oxidation, depressed glycogenesis, insulin resistance, and increased glucagon and catecholamine activities (Mizock 1995).

During acute-phase situations due to tissue damage, the liver is exposed to the acute-phase mediators produced by inflammatory cells, which induce metabolic changes and a dramatic change of the protein synthesis in the hepatocytes. Furthermore, corpusculate materials like tissue debris and damaged erythrocytes are taken up by liver macrophages that stimulate them to synthesize tumor necrosis factor- $\alpha$ (TNF- $\alpha$ ), interleukin-6 (IL-6) and interleukin-1 $\beta$ (IL-1 $\beta$ ) or interferon- $\gamma$ (Ramadori and Christ 1999). These cytokines together with those synthesized at the injury site can also induce synthesis of other mediators by the Kupffer cells and by the hepatocytes such as CXCL8 (IL-8) (Sheikh et al. 2006) or CCL2 (MCP-1) (Malik et al. 2010b).

Some of these mediators are also known to exert metabolic effects. In fact, upregulation of CXCL10 is thought to be linked to increased fatty acid production in the liver of obese hepatitis C virus (HCV)-infected patients (Palmer et al. 2010). Furthermore, CCL2 is known to be associated with insulin resistance (Sartipy and Loskutoff 2003) as was reported for IL-6 (Wallenius et al. 2002).

Hepatocytes not only express the receptors for different cytokines, but also receptors for several hormones such as glucocorticoids (Engblom et al. 2007), thyroid hormones (Malik et al. 2010a), insulin (Fehlmann et al. 1982) and leptin as mentioned above (Vrang et al. 2002). Moreover, it is also known that the leptin serum level is elevated in acute-phase conditions, caused by the administration of, e.g., lipopolysaccharide (LPS) or turpentine oil (TO) (Faggioni et al. 1998).

According to previous reports, expression of MCRs was mainly found in the murine central nervous system (CNS) (Gantz and Fong 2003; Mountjoy et al. 1992), from where they can exert their effects on other organs (Toda et al. 2009) outside the brain, such as the liver (Bitto et al. 2011). However, the detection or direct influence of MCRs in the liver has not been reported in the literature so far.

As mentioned above, the liver is the major metabolic organ and also the main target organ during APR. The present study addresses the question of whether the MCRs are expressed in rat and mouse liver cells. Apart from detecting MC4R in the liver and in liver cells, we also demonstrate that tissue damage induced by the intra-muscular administration of turpentine oil can induce changes in the hepatic expression of MCRs at the mRNA and protein level. The results of our in vitro experiments suggest that these changes could have an important metabolic and eventually local anti-inflammatory function under normal and pathological conditions.

\section{Methods}

Antibodies

A rabbit polyclonal antibody specific to MC4R and MC3R was obtained from Abcam (Cambridge, USA); a monoclonal 
Table 1 Rat primer sequences used in this study

\begin{tabular}{lll}
\hline Primer & $5^{\prime}-3^{\prime}$ Forward & 5'-3' Reverse \\
\hline MC1R & GGTGTCCAGTCTCTGCTTCC & GGGACAGTGTCACAATGCTG \\
MC2R & CGCTACATCACCATCTTCCA & CCGCTCCCTGTACAGAACAT \\
MC3R & GGCGTGATGTTCATCGTCTA & GCGAAGAGGAACATGTGGAT \\
MC4R & CAC AGT ATC GGG CGT TCT TT & GTA ATT GCG CCC TTC ATG TT \\
MC5R & TGTTCGACTCCATGATCTGC & CGTCATGATGTGGTGGTAGC \\
IL-6 & GTC AAC TCC ATC TGC CCT TCA G & GGC AGT GGC TGT CAA CAA CAT \\
TNF- $\alpha$ & ACA AGG CTG CCC CGA CTA T & CTC CTG GTA TGA AGT GGC AAA TC \\
IL-1 $\beta$ & TAC CTA TGT CTT GCC CGT GGA G & ATC ATC CCA CGA GTC ACA GAG G \\
CXCL10 & CTGTCGTTCTCTGCCTCGTG & GGATCCCTTGAGTCCCACTCA \\
CCL2 & AGGCAGATGCAGTTAATGCCC & ACACCTGCTGCTGGTGATTCTC \\
$\beta-A c t i n$ & ACCACCATGTACCCAGGCATT & CCACACAGAGTACTTGCGCTCA \\
UBC & CACCAAGAAGGTCAAACAGGAA & AAGACACCTCCCCATCAAACC \\
\hline
\end{tabular}

antibody specific to $\beta$-actin was purchased from Sigma (Munich, Germany). We also bought mouse anti-rat ED1 monoclonal antibody, Serotec (Duesseldorf, Germany), mouse anti-SMA Sigma (Munich, Germany) and mouse antiCK19 Novocastra (Newcastle upon Tyne, UK) antibodies.

Induction of acute-phase reaction (APR)

APR was induced and organs were removed as described previously (Ramadori et al. 2010). Briefly, tissue damage was induced by injecting $5 \mathrm{ml} / \mathrm{kg}$ TO to male Wistar rats (about $200 \mathrm{~g}$ body weight) and $10 \mathrm{ml} / \mathrm{kg}$ to male B6.129S2$1 l 6^{\mathrm{tm} 1 \mathrm{Kopf}}$ (IL-6 KO) mice and male C57BL/6J (wild-type) mice (about 25-28 g body weight) in both right and left hind limbs of the animals; and an intraperitoneal injection with $50 \mu \mathrm{g}$ LPS from E. coli serum type was given. Control animals were treated in the same way for each time point, but with saline injection in both limbs. All animals were cared for according to the university's guidelines, German regulations for the protection of animals and NIH guidelines.

\section{Isolation of total RNA and real-time-PCR}

Total RNA was isolated and converted into cDNA for RT-PCR from rat tissues and cells according to a protocol described already (Malik et al. 2010a). The housekeeping genes ubiquitin $\mathrm{C}$ (UBC) and $\beta$-actin were used as normalizers. Primer sequences used are shown in Table 1. All samples were assayed in duplicate. The cDNA was amplified by running RT-PCR samples in a $1 \%$ agarose electrophoresis gel at $80 \mathrm{~V}$ for $1 \mathrm{~h}$. DNA bands were visualized by intercalating ethidium bromide staining (Sigma, Munich, Germany).

Tissue sections and immunohistochemistry

Peroxidase staining (POD) and immunofluorescence staining were performed as described before (Malik et al. 2010b) with an antibody directed against MC4R diluted in PBS in the ratio of $1: 100$.

Isolation of tissue lysates, cytosolic lysates and nuclear protein extracts

Tissue lysates, nuclear protein and cytosolic extracts from rat liver were prepared as described previously (Malik et al. 2010a; Ramadori et al. 2010).

Immunoprecipitation

As much as $40 \mu \mathrm{l}$ of liver tissue homogenate and $400 \mu \mathrm{l}$ of PBS containing protease inhibitors (Roche, Mannheim, Germany) were incubated with $50 \mu$ protein A-agarose (Roche, Mannheim, Germany) for $1 \mathrm{~h}$ at $4^{\circ} \mathrm{C}$ under rotation. The sample was centrifuged for $30 \mathrm{~s}$ at $6,000 \mathrm{rpm}$ and $4 \mu \mathrm{l}$ of the rabbit polyclonal antibody against MC4R was added to the supernatant. After incubation for $6 \mathrm{~h}$ at $4^{\circ} \mathrm{C}$ under rotation, the sample was incubated with $50 \mu \mathrm{l}$ of protein A-agarose for $16 \mathrm{~h}$ under the same conditions. The sample was centrifuged for $5 \mathrm{~min}$ at $6,000 \mathrm{rpm}$ and the supernatant was discharged. The pellet was washed with PBS and then resuspended in $25 \mu$ of ultrapure water, and $15 \mu \mathrm{l}$ of the suspension was analyzed with Western blot.

Western blot analysis

The Western blot was performed as described previously (Malik et al. 2010a) by using $50 \mu \mathrm{g}$ total protein and $30 \mu \mathrm{g}$ nuclear extracts. The primary antibody to MC4R and MC3R was used at a 1:100 dilution.

Immunizing peptide

For experiments with the immunizing peptide, we used a concentration of the rabbit polyclonal anti-MC4R antibody 
of $2 \mu \mathrm{g} / \mu \mathrm{l}$ diluted in TBS-T with $2.5 \%$ milk divided equally into two tubes. Into the first tube was added $1 \mu \mathrm{g} / \mathrm{ml}$ of MC4R immunizing peptide (Abcam, Cambridge, USA). The second tube contained the anti-MC4R antibody with no immunizing peptide. Both tubes were incubated at room temperature for $30 \mathrm{~min}$. A membrane containing liver tissue lysate in all lanes was split in half. One piece of the membrane was incubated with the solution containing the antiMC4R antibody that was neutralized with the immunizing peptide, and the other one with the untreated antibody.

Enzyme-linked immunosorbent assay (ELISA)

$\alpha$-MSH (ELISA for $\alpha$-MSH: cat. no: EK-043-01, Phoenix Pharmaceuticals, Burlingame, USA) and leptin (cat. no. RL-83K Millipore, Billerica, USA) levels in serum were determined using commercially available ELISA kits according to the instructions of the manufacturer.

Isolation of rat liver macrophages (Kupffer cells) and hepatocytes

Kupffer cells and hepatocytes were isolated according to the method described previously (Malik et al. 2010b) The Kupffer cells were exposed to $5 \mu \mathrm{M} \alpha$-MSH (Tocris Bioscience, Missouri, USA) and $5 \mu \mathrm{M}$ THIQ ([(N-[(3R)-1,2,3, 4-tetrahydroisoquinolinium-3-ylcarbonyl]-(1R)-1-(4-chlorobenzyl)-2-[4-cyclohexyl-4-(1H-1,2,4-triazol-1-ylmethyl) piperidin-1-yl]-2-oxoethylamine) (Tocris Bioscience, Missouri, USA) in the presence or absence of $10 \mu \mathrm{g} / \mathrm{ml}$ concentration of LPS (Sigma, Munich, Germany), whereas hepatocytes were only exposed to $5 \mu \mathrm{M} \alpha$-MSH and $5 \mu \mathrm{M}$ THIQ in 3 -ml cell culture medium. The Kupffer cells and hepatocytes were then harvested in all in vitro experiments at 1,3 and $6 \mathrm{~h}$ after treatment. Non-treated cells of all studied time points served as controls in all experiments.

\section{Statistical analysis}

The PCR data were analyzed using Graph Pad Prism 4 software (San Diego, USA). All experimental errors are shown as SEM. Statistical significance was calculated by one-way ANOVA and Dunnett's post hoc test. Significance was accepted at $P<0.05$.

\section{Results}

Change in MCRs gene expression during APR in rat

By means of RT-PCR analysis, the presence of all MCRs was detected at the mRNA level in the rat liver tissue of control animals. An early increase of MC4R gene expres- sion, starting from $1 \mathrm{~h}$ and reaching a maximum $(6.3 \pm 2.3-$ fold) at $6 \mathrm{~h}$, could be observed after the onset of APR; however, the gene expression of MC4R remained above the control level for $36 \mathrm{~h}$. A significant upregulation in gene expression of MC2R (3.5 \pm 0.9 -fold $)$ and MC5R (3.8 \pm 0.9 -fold) was detected with a maximum of $12 \mathrm{~h}$, whereas a mild increase in gene expression of MC1R $(2.6 \pm 0.3$-fold at $2 \mathrm{~h})$ and MC3R $(2.1 \pm 0.2$-fold at $12 \mathrm{~h})$ was also found (Fig. 1a). The detection of MCRs genes in liver tissue was confirmed by analyzing the PCR product through agarose gel-electrophoresis and comparing it to brain tissue at the RNA level (Fig. 1b).

Immunodetection of MCRs in rat liver and brain tissue sections

By means POD and immunofluorescence staining, using a rabbit polyclonal antibody against MC4R, a strong nuclear and to a lesser extent also a cytoplasmic reactivity was detected mainly in the hepatocytes of the control livers (Fig. 2; Fig. S1). In liver, positivity was also noticed in and around the cells of vessel walls of portal and central areas and in ED1-, CK-19 and SMA ${ }^{+}$cells of the liver (Fig. 3). An increase in the nuclear expression of MC4R with a parallel decrease in the cytoplasmic expression was also observed with onset of APR.

Similar to what was observed in the liver, POD and immunofluorescence staining directed against MC4R revealed a pattern of strong nuclear and weak cytoplasmic positivity in brain sections. The reactivity of MC4R was not only observed in cells with small nuclei (microglia), but also in cells with large nuclei (macroglia) in brain sections (Fig. 4a, b; Fig. S2). In contrast to nuclear expression of MC4R, a strong cytoplasmic expression of MC3R in the hepatocytes was detected in the liver tissue. A similar pattern was also noticed in brain sections (Fig. 5a, b). In brain tissue sections, MC3R and MC4R were used as a positive control in this study, as both are known to be constitutively expressed in the brain (Mountjoy et al. 1992; Tao 2010).

The negative control of the indirect immunofluorescence staining, a tissue section incubated with unspecific rabbit immunoglobulins instead of the specific antibody to MC4R, showed no specific signals (Figs. S1, S2).

MC4R protein level in liver tissue during APR

Using antibody against MC4R, immunoprecipitation (IP) of liver tissue proteins revealed an immunoreactive band at 37 and $55 \mathrm{kDa}$ in the liver tissue lysate. However, in the supernatant using the same antibody, only a band at $55 \mathrm{kDa}$ was visible, indicating that this band was more abundant than the lower molecular weight band (Fig. S3). Similar bands of MC4R were also detected by Western blot analysis in the 
Fig. 1 qRT-PCR analysis of total RNA from rat liver during acute-phase reaction. a Fold change in mRNA expression of MC1R, MC2R, MC3R, MC4R and MC5R; the TO-treated liver at different time points (1-48 h) related to saline-treated controls for each time point. qRT-PCR was normalized by using two housekeeping genes: $\beta$-actin and ubiquitin C. Results represent mean value \pm SEM of three animals, $* p<0.05$. b PCR analysis of total RNA extracted from rat brain and liver tissue. The PCR product was analyzed by agarose $(1.5 \%)$ gel electrophoresis (UV light picture)
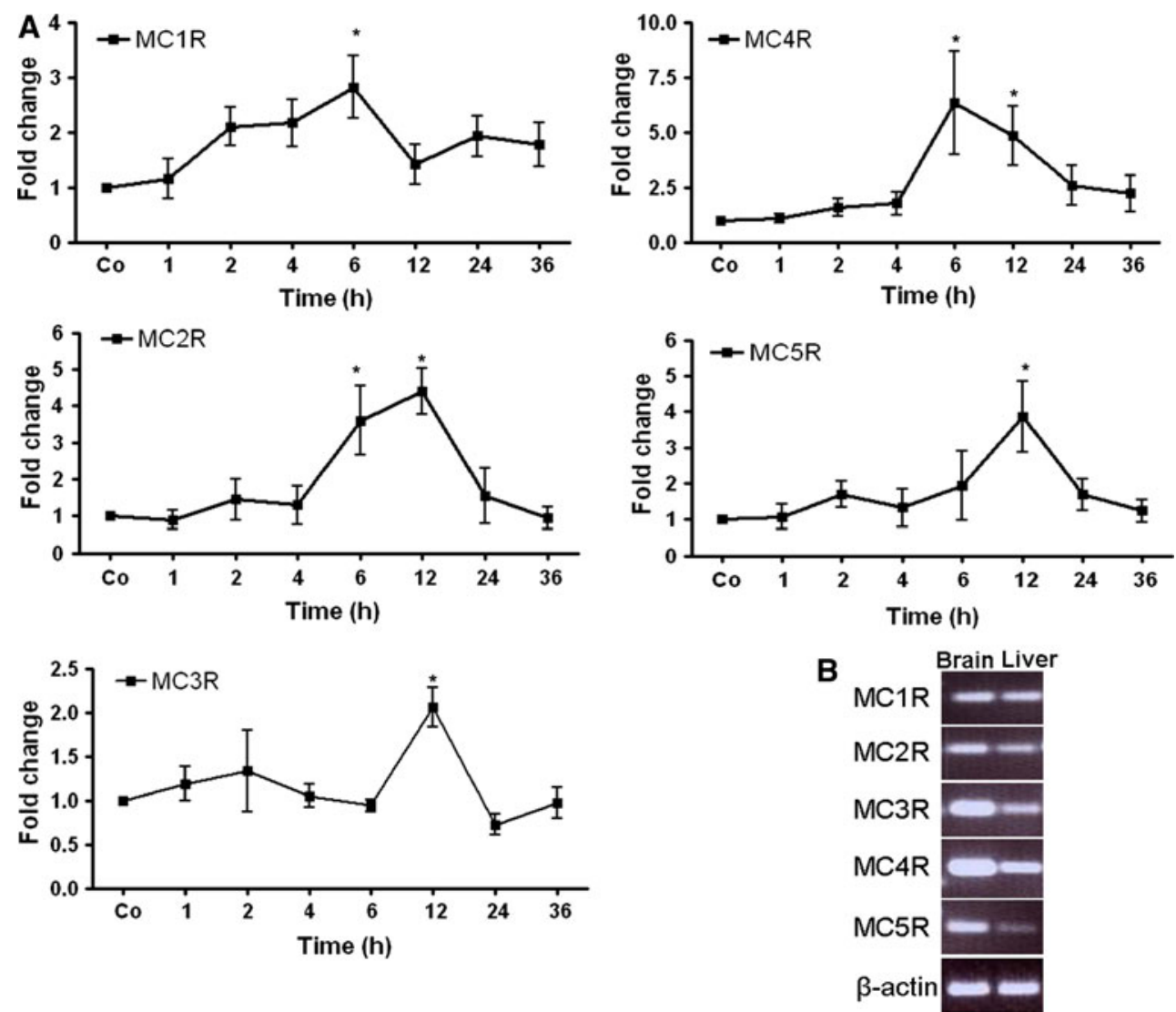

total liver tissue lysate, cytosol, nuclear fractionation of the protein and hepatocytes (Fig. 6a). To further assess the specificity of the two immunoreactive bands of MC4R by Western blot, we blocked anti-MC4R antibody using specific immunizing peptide against MC4R, but detected no band on the same membrane. In a second step, after stripping and by using the antibody against MC4R on the same membrane again, recovery of both the bands was observed (Fig. 6b). Furthermore, MC4R protein expression increased in nuclear extract of the liver with a maximum at $6 \mathrm{~h}$, whereas at the same time a decrease in cytoplasmic fraction of the liver could also be detected by Western blot analysis during APR (Fig. 6c). Consistent with the results obtained in liver, an increase of MC4R was also observed in rat brain after TO administration (used as a positive control) (Fig. 6d).

Similar to MC4R, a weak and time-dependent increase of MC3R was also detected by Western blot in rat liver tissue lysate after TO administration (Fig. 6e).

Changes in $\alpha$-MSH and leptin serum levels in TO-treated rats

After TO administration, a mild increase in the level of $\alpha$-MSH was detected with a maximum at $6 \mathrm{~h}(60 \pm 15 \mathrm{pg} / \mathrm{ml})$ in comparison to control rats $(32 \pm 6.2 \mathrm{pg} / \mathrm{ml})$. These changes, however, were not statistically significant. The leptin serum level was elevated early $(1 \mathrm{~h})$ above control $(1.2 \pm 0.7 \mathrm{ng} / \mathrm{ml})$ with a maximum at $6 \mathrm{~h}(6.3 \pm 0.8 \mathrm{ng} / \mathrm{ml})$ and remained significantly increased until $24 \mathrm{~h}$ after TO injection (Fig. 6f).

Detection and change in MC4R protein level in liver tissue of wild-type and IL-6-KO mice during APR

Similar to that observed in rat liver tissue, immunofluorescence staining showed a strong nuclear and, to a lesser extent also a cytoplasmic, reactivity in hepatocytes and macrophages (F4/80 ${ }^{+}$cells) of mice (Fig. 7).

By means of immunoblotting, an increase of MC4R protein levels in the liver tissue lysate of wild-type mice was also detected after onset of APR. An MC4R protein expression in the liver of wild-type mice started increasing at $4 \mathrm{~h}$, with a maximum at $6 \mathrm{~h}$ and remained above control level until $24 \mathrm{~h}$ in both TO- and LPS-treated mice. However, a parallel and time-related decrease with a minimum at $12 \mathrm{~h}$ was observed in IL-6-KO mice in both APR models (Fig. 6g, h).

Immunohistochemical detection of MC4R in primary cultured Kupffer cells, hepatocytes and Hep G2 cells

By using the antibody against MC4R, immunofluorescent detection revealed MC4R in the nucleus and more weakly 

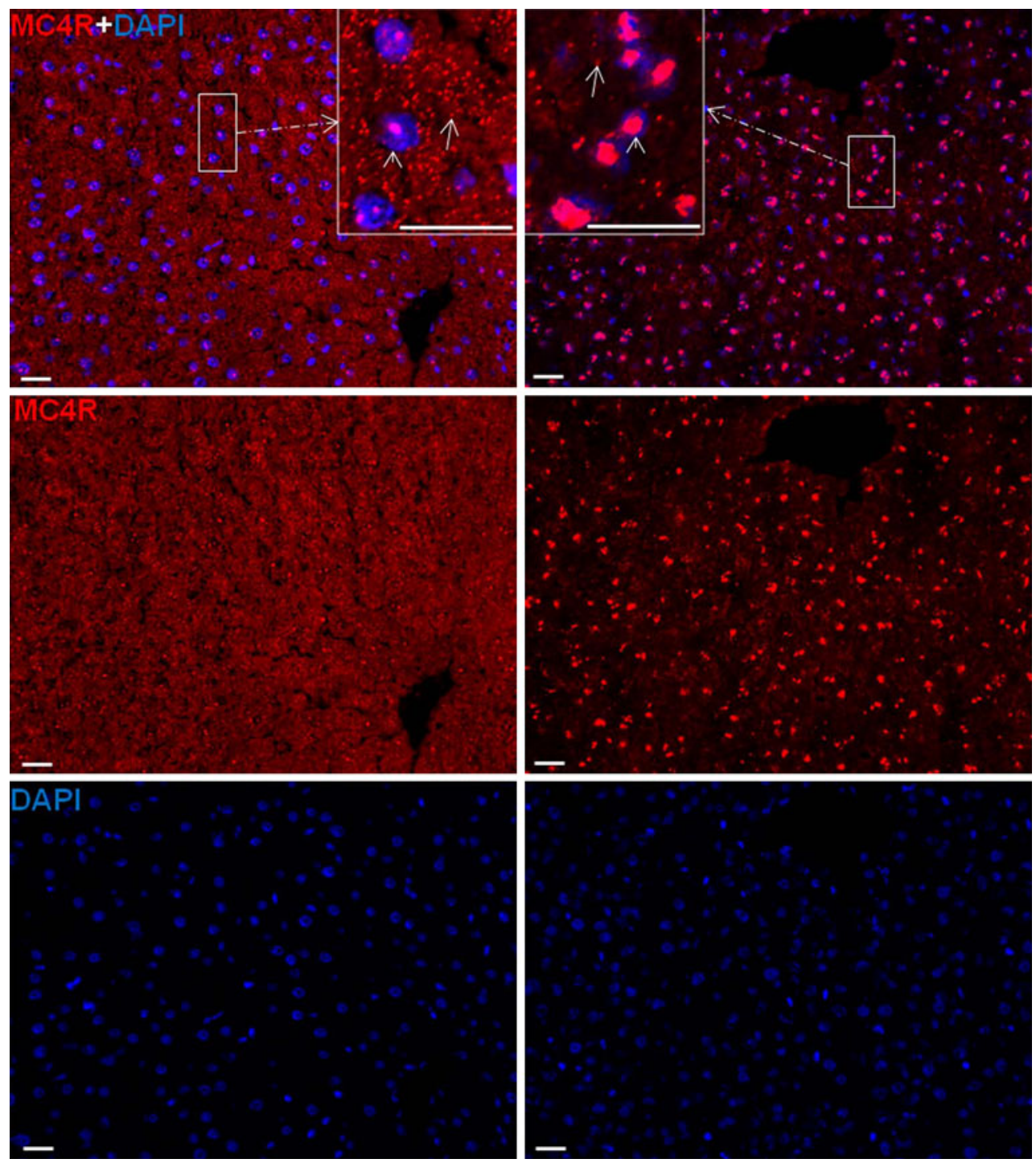

Fig. 2 Immunofluorescence staining of liver sections with polyclonal antibody directed against MC4R (red), followed by fluorescent immunodetection in rat liver sections during acute-phase response after TO treatment. Left control liver, right $6 \mathrm{~h}$ after TO treatment. Upper

MC4R and DAPI staining; middle MC4R staining; lower DAPI staining. Inset shows higher magnification. Results show the representative picture of three animals and six slides per time point (original magnification, $\times 200$, scale bar $20 \mu \mathrm{m}$ )

in the cytoplasm of cultured Kupffer cells, hepatocytes and Hep G2 cells, confirming the in vivo data. However, Kupffer cells showed the strongest expression among all other stained cells (Fig. 8a-c).

\section{Change in gene expression of MCRs in $\alpha$-MSH} and THIQ-treated primary cultured rat Kupffer cells and hepatocytes

We investigated the gene expression of MCRs at the mRNA level in cultured Kupffer cells and hepatocytes at different time points $(2,4$ and $6 \mathrm{~h})$ after treatment with $\alpha$-MSH (MCRs agonist) and THIQ (specific MC4R agonist) and compared them to non-treated controls for each time

point. An early and strong change in the gene expression of MC4R ( $3.9 \pm 0.3$-fold at $2 \mathrm{~h})$ was observed after treatment of Kupffer cells with THIQ. Similar findings were also observed in MC4R gene expression after treatment with $\alpha$-MSH (MCRs agonist); however, the THIQ effect was faster and stronger. Moreover, stimulation with THIQ also upregulated the gene expression of MC2R; this effect was stronger than that observed after treatment with $\alpha-\mathrm{MSH}$. Treatment of Kupffer cells with $\alpha$-MSH upregulated gene expression of MC3R followed by MC5R and MCR1, whereas in comparison to non-treated controls, a mild change was also detected in MC5R followed by MC3R and MC1R at the mRNA level after treatment with THIQ (Fig. 9). 

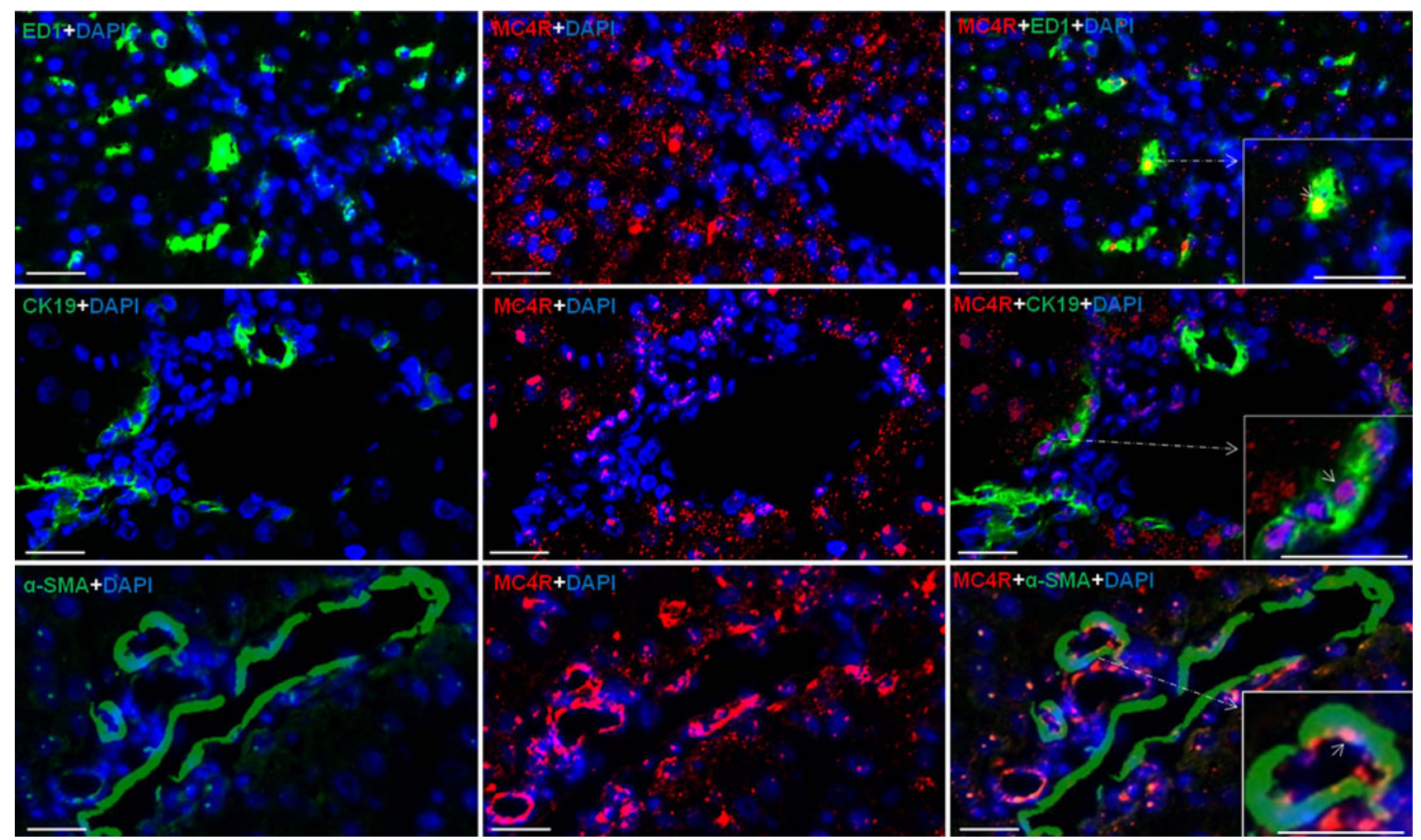

Fig. 3 Immunofluorescence staining in rat liver sections with monoclonal antibody against ED1 (upper left, green), polyclonal antibody directed against MC4R (upper middle, red) and merged ED1 and MC4R (upper right); middle staining with monoclonal antibody against CK-19 (middle left, green), polyclonal antibody directed against MC4R (middle, red) and merged CK-19 and MC4R (middle right); lower staining with monoclonal antibody against SMA (lower left, green), polyclonal antibody directed against MC4R (middle, red) and merged SMA and MC4R (lower right) followed by fluorescent immunodetection. Inset shows higher magnification. Results show the representative picture of three animals and six slides per time point (original magnification, $\times 100$, scale bar $20 \mu \mathrm{m}$ )

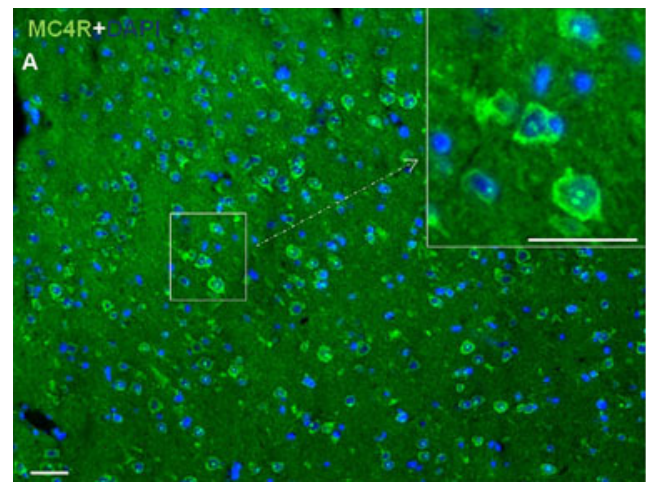

Fig. 4 Immunofluorescence staining of brain sections with polyclonal antibody directed against MC4R (green) followed by fluorescent immunodetection in sections of rat brain during APR. a Control brain

By means of RT-PCR analysis, the presence of all MCRs was also detected at the mRNA level in the isolated cultured rat hepatocytes. Though lower in magnitude than in the Kupffer cells, a similar pattern of increase was observed in the rat hepatocytes after $\alpha$-MSH and THIQ treatment (data not shown).

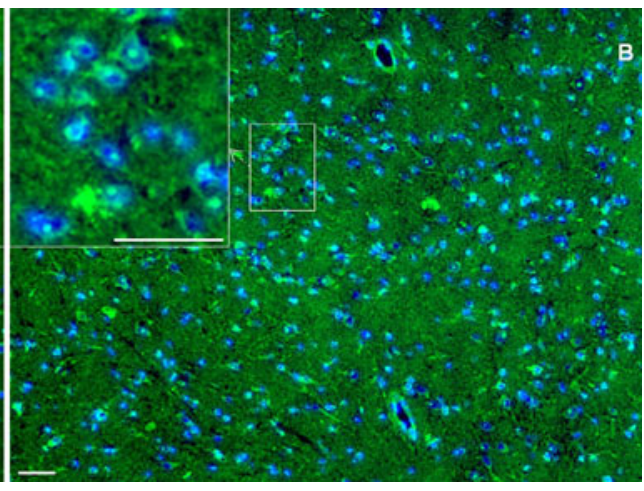

section and $\mathbf{b} 6 \mathrm{~h}$ after TO treatment. Results show the representative picture of three animals and six slides (original magnification, $\times 100$, scale bar $10 \mu \mathrm{m}$ )

Change in gene expression of acute-phase cytokines and chemokines in $\alpha$-MSH and THIQ-treated primary cultured Kupffer cells and hepatocytes

In isolated Kupffer cells, mRNA of pro-inflammatory cytokines was significantly increased compared to untreated 


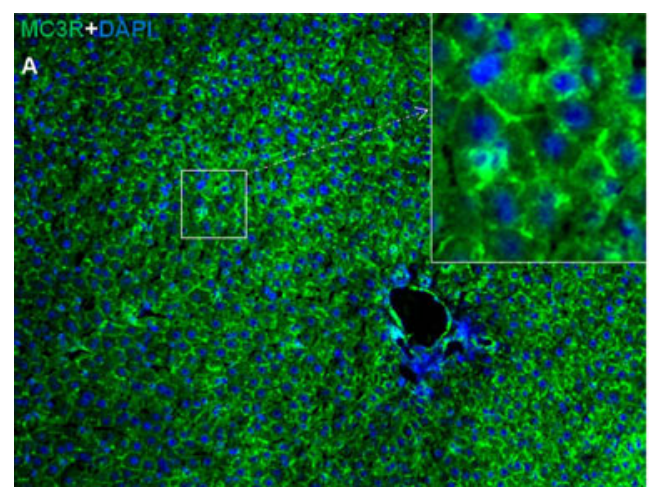

Fig. 5 Immunofluorescence staining of liver and brain sections during APR. Immunofluorescence staining with polyclonal antibody directed against MC3R $\mathbf{a}$ in liver sections (green) and $\mathbf{b}$ brain section (red) fol-

controls upon exposure to LPS. The early $(2 \mathrm{~h})$ increase in the cytokine group was observed with a maximum in gene expression of TNF- $\alpha$ at $4 \mathrm{~h}$ (182 \pm 15 -fold), followed by IL-6 (123 \pm 4 -fold) and IL- $1 \beta$ (52 \pm 2 -fold) at $6 \mathrm{~h}$ after LPS treatment. The upregulating effect of LPS on TNF- $\alpha$, IL- 6 and IL- $1 \beta$ was significantly reduced by 40,70 and $46 \%$, respectively, by adding $\alpha$-MSH together with LPS in culture medium. Gene expression of cytokines was also significantly reduced by the addition of THIQ together with LPS; however, the reducing effect of $\alpha$-MSH was higher on IL- 6 and IL1 $\beta$ than on THIQ. The reduction in gene expression of TNF- $\alpha$ was similar with treatment of both molecules in the presence of LPS (Fig. 10a).

In isolated cultured hepatocytes, gene expression of CCL2 and CXCL10 was significantly downregulated (up to $60 \%$ ) after $4-6 \mathrm{~h}$ of exposure to $\alpha$-MSH or THIQ, respectively (Fig. 10b).

\section{Discussion}

In this study, to the best of our knowledge, we demonstrate for the first time the presence of melanocortin receptors (MCRs) in rat and mouse liver cells. An upregulation in gene expression of MCRs in the liver and brain tissue was detected in an acute-phase model induced by TO damage to skeletal muscle. In parallel, an increase in $\alpha$-MSH level and a significant increase in leptin rat serum level were found. After intramuscular TO injection, a "migration" of MC4R protein from cytoplasm to the nucleus could be detected by immunohistochemistry and Western blot analysis of the cell fractions.

A similar pattern of increase in MC4R level was also observed in the liver of two mice models of acute-phase reaction, although the order of magnitude of the changes observed in the liver of IL-6ko mice was much lower than that observed in the wild-type animals.

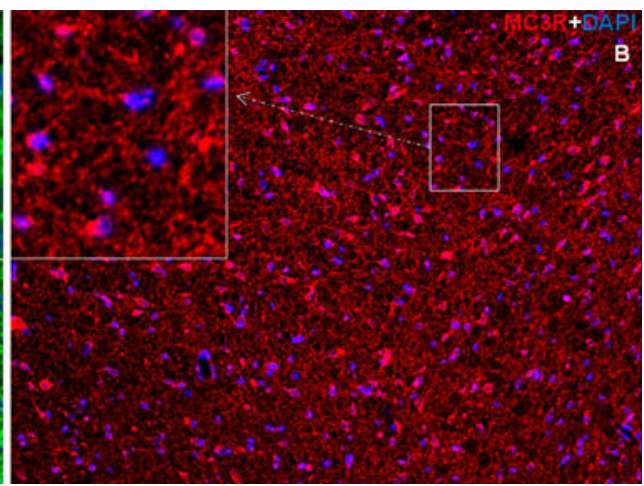

lowed by fluorescent immunodetection during APR. Inset shows higher magnification. Results show the representative picture of three animals and six slides (original magnification, $\times 100$, scale bar $10 \mu \mathrm{m}$ )

To demonstrate the distribution and change of MC4R gene expression in the liver taking place under the experimental conditions used, we showed a change of MC4R gene expression in rat brain tissue similar to that observed in liver tissue. In fact, MC4R gene expression significantly increased during the time after tissue damage was induced in the muscle. Both immunoprecipitation and Western blot analysis showed a probable non-glycosylated $(37 \mathrm{kDa})$ and glycosylated $(55 \mathrm{kDa})$ band of MC4R in liver tissue lysate. In previous studies, in addition to a 55-kDa band, dimerization of MC4R has also been reported (Biebermann et al. 2003; Elsner et al. 2006).

In contrast to treatments inducing an acute systemic response and also liver damage, such as administering bacterial endotoxin LPS (Caruso et al. 2007), TO is known to induce aseptic local abscesses without detectable injury to other tissues (Malik et al. 2010a; Sheikh et al. 2006). Therefore, the TO-induced APR model allows us to study the effect of cytokines produced at distant sites in the liver. It reproduces the changes observed in human disease states due to localized tissue injury (Malik et al. 2010a; Ramadori and Christ 1999; Sheikh et al. 2006), making it an ideal model for studying the metabolic consequences of human APR.

The melanocortin system consists of several agonists, apart from $\alpha$-MSH (native specific agonist of MCRs); the discovery of an orally active non-peptide MC4R mimetic, called THIQ (selective agonist of MC4R), has also been reported (Sebhat et al. 2002). THIQ-stimulated 3',5'-cyclic monophosphate (cAMP) generation is reported to act similarly to that induced by $\alpha$-MSH in human as well as in rat MC4R assays (Sebhat et al. 2002). $\alpha$-MSH exerts its effect by melanocortin receptors (MCRs) and is known to be produced in the pituitary gland, brain and several peripheral tissues, including immune cells, by posttranslational processing of the pro-opiomelanocortin precursor protein (Gantz and Fong 2003; Mountjoy et al. 1992; Tao 2010). 


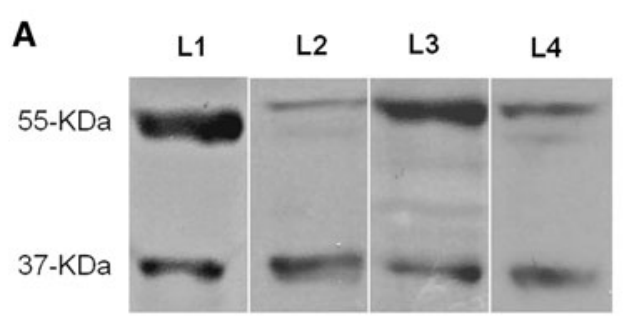

C

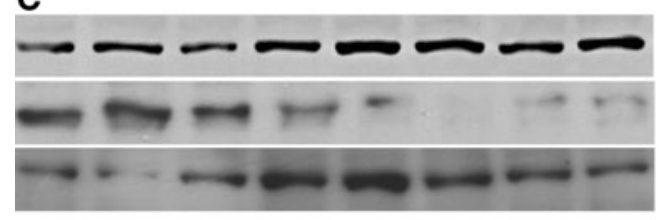

D

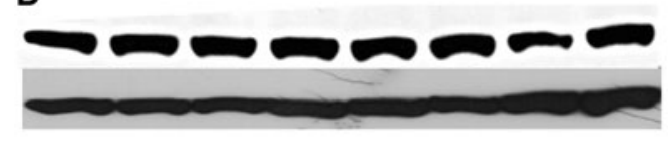

E

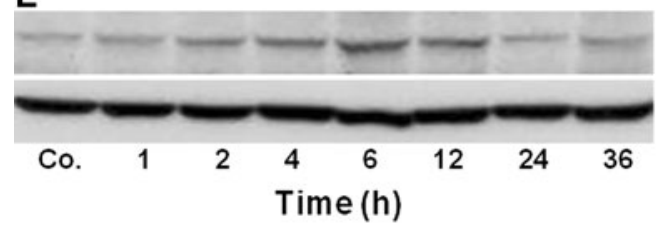

B
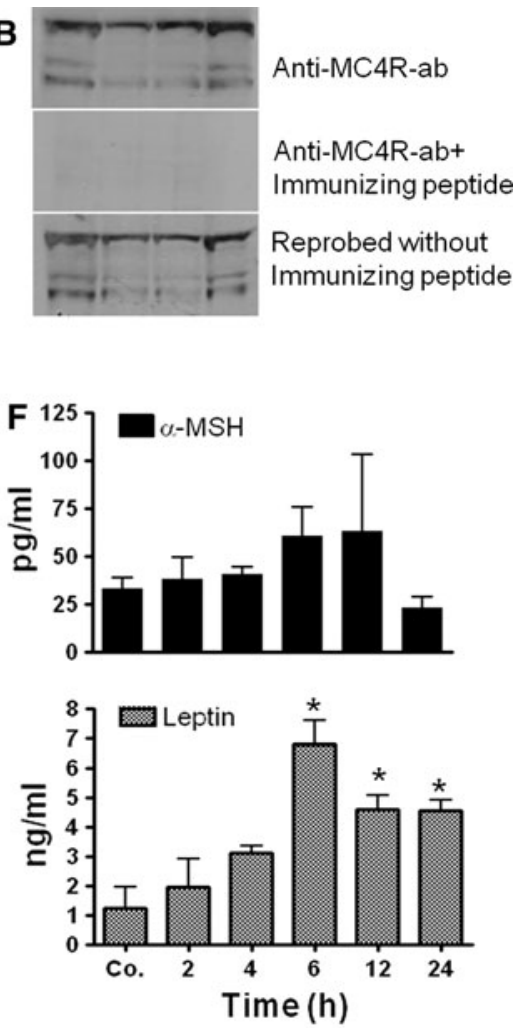

IL-6 ko

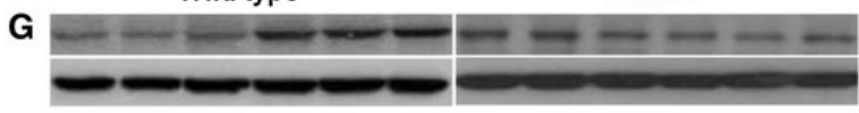

H

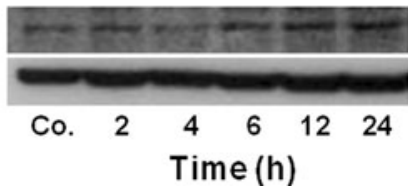

(6) Co.

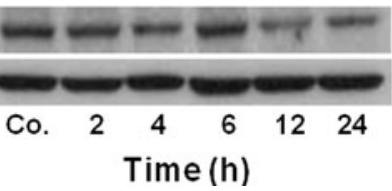

Fig. 6 Detection of MC4R and MC3R by Western blot analysis of rat liver and brain. a Western blot analysis revealed two immunoreactive bands: one at $37 \mathrm{kDa}$ and a second at $55 \mathrm{kDa}$. Lane $(L) 1$ contains rat liver total lysate, $L 2$ liver cytosolic extraction, $L 3$ liver nuclear extracts and $L 4$ total protein of cultured rat hepatocytes. b Top rat liver total lysates with immunoreactive bands at 37 and $55 \mathrm{kDa}$, middle after neutralizing the anti-MC4R antibody with a specific immunizing peptide. Bottom reprobing of the same membrane with the antibody against MC4R without immunizing peptide. $\mathbf{c}$ Changes in MC4R protein level during APR. Top contains rat liver total lysate, middle liver cytosolic extraction, bottom liver nuclear extracts. d Identification and changes

We showed that MCRs were not only expressed in the rat liver cells, but also that their gene expression was upregulated at the mRNA and protein level during acute-phase response. An upregulation in MCRs gene expression is known to be due to an increased concentration of their agonist(s) (Gantz and Fong 2003). The binding of the agonist to the receptor in the cytoplasm and its migration to the nucleus could explain the increase of the MC4R protein in in MC4R level in rat brain total lysate during APR, e detection and changes of MC3R level in rat liver total lysate. f Changes in serum concentration of $\alpha$-MSH and leptin during APR. $\alpha$-MSH (top) and leptin (bottom) levels were measured with enzyme-linked immunosorbent assay (ELISA). Results represent mean value \pm SEM $(* P<0.05$ analyzed by one-way ANOVA; $n=3$ ). $\mathbf{g}$ Detection of MC4R in the liver of wild-type and IL-6-ko mice during APR. Total protein lysate of mouse liver after TO administration; $\mathbf{h}$ total protein lysate of mice liver after LPS treatment. $\beta$-actin (43 kDa) was used as equal loading control in Western blot analysis. Results show the representative picture of three animals

the nuclear fraction during APR. In fact, this observed migration of MC4R could be due to its binding not only to $\alpha-\mathrm{MSH}$, but also to leptin, as leptin is also able to directly interact with the melanocortin system in mouse brain (Vrang et al. 2002), and inhibition of MC4R attenuates the leptin signaling in rat brain (Seeley et al. 1997). This could be true for liver as well, because an increased serum level of leptin was also detected in our studied model. Moreover, 
leptin receptors are known to be expressed in hepatocytes (Cohen et al. 2007). A similar mechanism of cytoplasm to nuclear movement has already been reported in glucocorti-
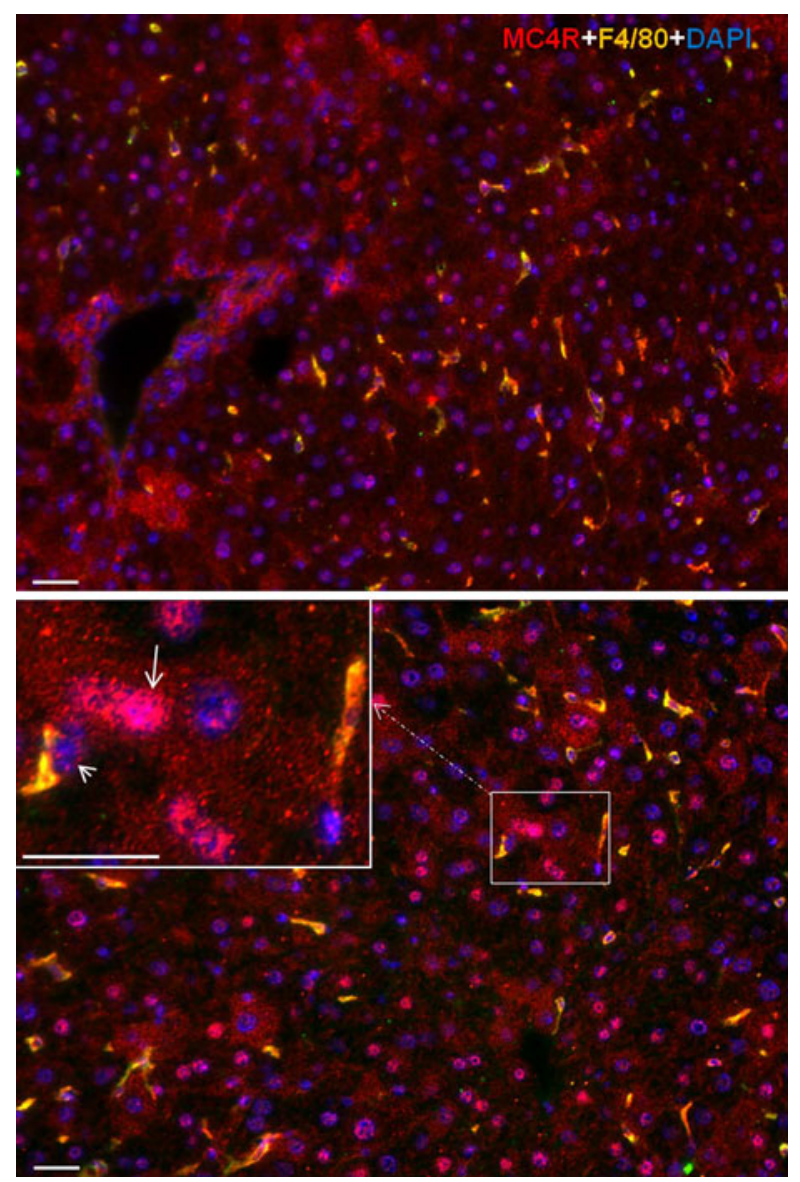

Fig. 7 Double immunofluorescence staining with polyclonal antibody directed against MC4R (red) and F4/80 (green) followed by fluorescent immunodetection in sections of mouse liver during APR. Upper control liver, lower $6 \mathrm{~h}$ after TO treatment. Inset shows higher magnification. White arrow indicates the hepatocytes positive for MC4R and white arrowhead indicates the Kupffer cells positive for MC4R and F4/ 80. Results show the representative picture of three animals and six slides (original magnification, $\times 200$, scale bar $20 \mu \mathrm{m}$ ) coid receptors (Picard and Yamamoto 1987) and insulin receptors (Fehlmann et al. 1982) after binding to their ligand. A link between and leptin and the melanocortin system has already been established. A previous study on rats showed that leptin regulates the glucose fluxes of hepatic and peripheral tissues through a melanocortin-dependent pathway (Shimizu et al. 2007; Toda et al. 2009). Another study stated that mice lacking OB-Rb (leptin receptor) in POMC neurons show hyperinsulinemia (van de Wall et al. 2008). Likewise, glucose uptake by the effect of intra-ventromedial nucleus of the hypothalamus (VMH) leptin also depends on MC4R (Toda et al. 2009). Together, these studies clearly support a relationship between leptin and the melanocortin system of the brain.

As we previously showed, the serum level of IL-6 is dramatically elevated in the rat model of TO-induced APR (Sheikh et al. 2006). In this study, we analyze MC4R gene expression in IL-6ko mice using the same APR model. Strikingly, in the absence of IL-6, the increase of MC4R hepatic gene expression after TO injection was much lower than that observed in wild-type animals, indicating a direct, regulative function of this important acute-phase cytokine.

A contribution of cytokines (IL-6 and TNF- $\alpha$ ) to the manifestation of whole-body insulin resistance and to the direct regulation of glucose metabolism has already been described (Lazar 2005; Wallenius et al. 2002). Furthermore, IL-6 given peripherally at high doses can cause increased levels of blood lipids and blood glucose (Nonogaki et al. 1995). Administration of IL-6 could stimulate the mobilization and utilization of fatty acids and could also increase lipid metabolism (Glund and Krook 2008). Moreover, it can also acutely enhance circulating levels of triglycerides in rats (Nonogaki et al. 1995), suggesting the importance of this cytokine in APR-induced metabolic disorder.

The relation between leptin and melanocortin or leptin and cytokines has been studied partially (Shimizu et al. 2007; Vrang et al. 2002; Wallenius et al. 2002); however,

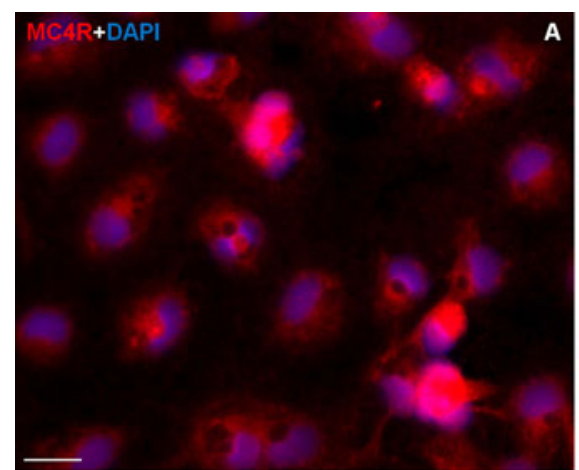

Kupffer cells

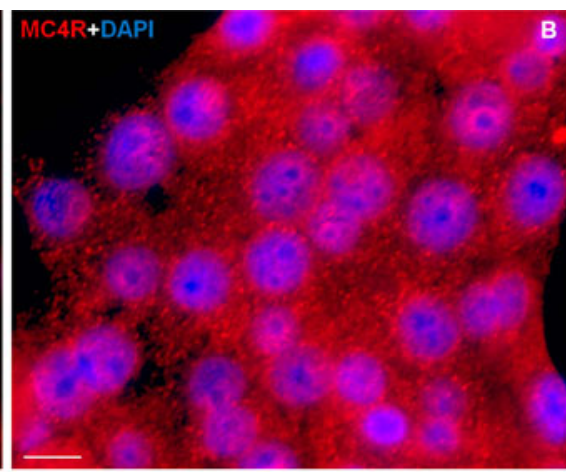

Hepatocytes

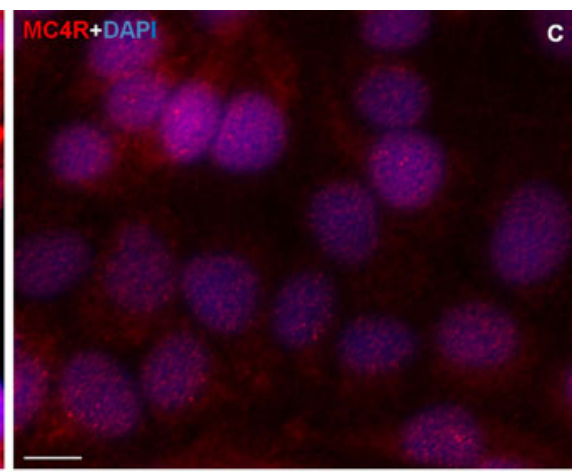

HepG2

Fig. 8 Immunofluorescence detection of MC4R in isolated rat a Kupffer cells, b hepatocytes and c human hepatoma cell line (HepG2). Results are representative of three experiments for each cell type (original magnification $\times 400$, scale bar $40 \mu \mathrm{m}$ ) 

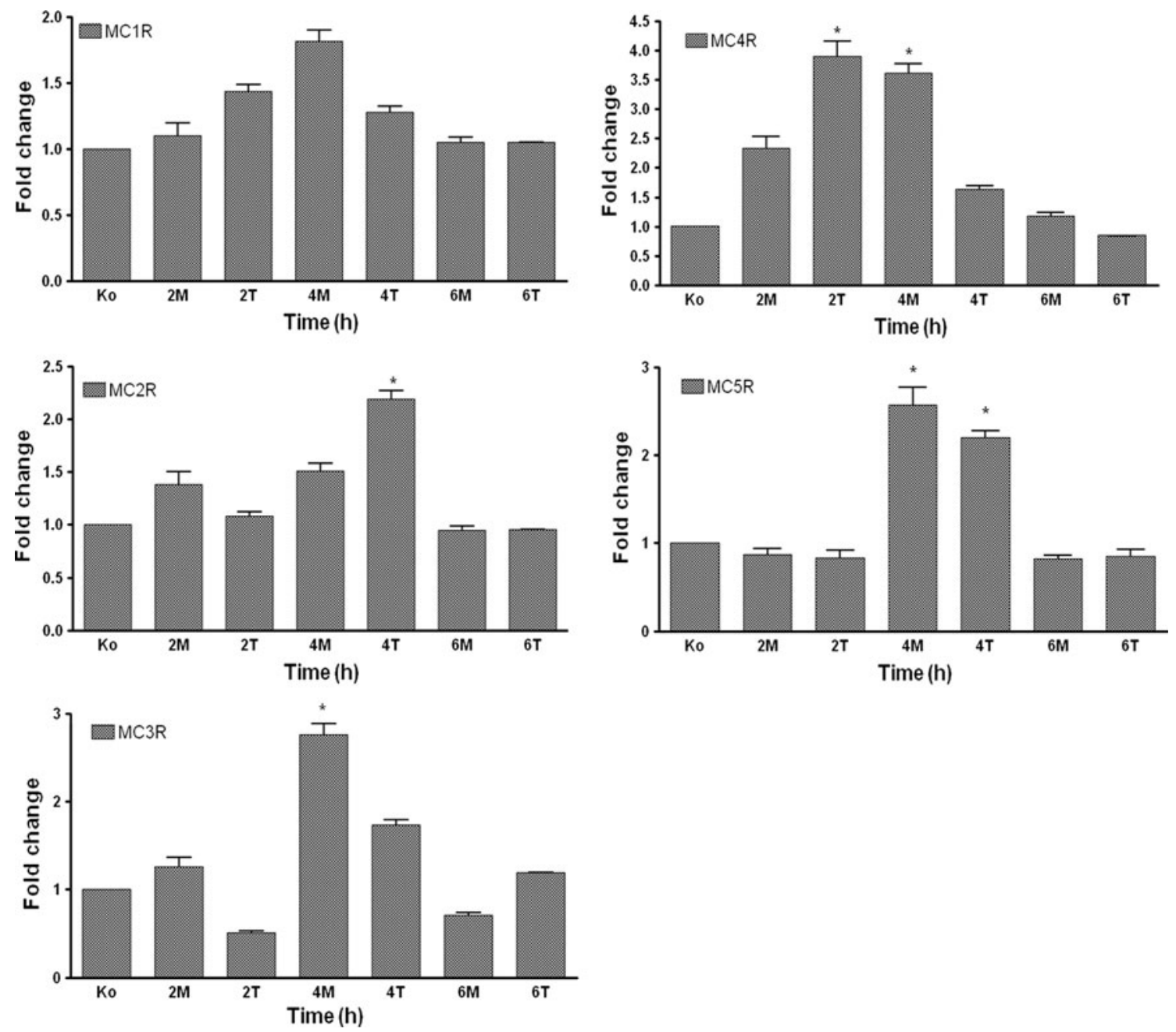

Fig. 9 RT-PCR analysis of total RNA from rat isolated Kupffer cells treated with $\alpha$-MSH and THIQ. Data shown as fold changes in mRNA expression of MC1R, MC2R, MC3R, MC4R and MC5R at different time points related to untreated controls for each time point. qRT-PCR

interaction among leptin, the melanocortin system and cytokines together has not been investigated so far. A previous report stated that despite the absence of IL-6, the serum leptin level was increased in IL-6ko mice during APR (Faggioni et al. 1998; Wallenius et al. 2002). This could suggest that although MC4R gene expression is not upregulated in the absence of IL-6, a strong metabolic effect could be achieved by the interaction between leptin and MC4R.

Consideration of our data further implies that the melanocortin system could have a dual role: on one hand, MC4R is not only the target of acute-phase cytokines, but may control their production as well.

In this study, we show that the melanocortin system influences energy metabolism at different levels during APR. In fact, it not only mediates the effect of acute-phase cytokines, but may also participate in controlling the synthesis of APR cytokines and chemokines in liver macro-

was normalized by using two housekeeping genes: $\beta$-actin and ubiquitin C. Results represent mean value \pm SEM of three experiments, $* p<0.05$

phages (Kupffer cells) and hepatocytes respectively. The latter have also been shown to have metabolic effects (Sartipy and Loskutoff 2003; Sell and Eckel 2009).

Indeed, in our current study, treatment of Kupffer cells with endotoxin lipopolysaccharide (LPS) increased gene expression of acute-phase mediators; this increase was significantly inhibited by $\alpha$-MSH and THIQ, respectively. Moreover, both agonists were able to downregulate the gene expression of potential chemokines in cultured rat hepatocytes.

In an additional experiment, IL-6 treatment of hepatocytes increased the gene expression of two major acute-phase proteins: $\alpha 2$-macroglobulin $(\alpha 2 \mathrm{M})$ and heme oxygenase-1 (HO-1); however, this upregulation of $\alpha 2 \mathrm{M}$ was transiently reduced in hepatocytes when $\alpha-\mathrm{MSH}$ was also added in the culture medium. In contrast, the effect of IL- 6 on expression of HO- 1 was not reduced by $\alpha$-MSH (manuscript in preparation). It may suggest that the main role of MC4R is 

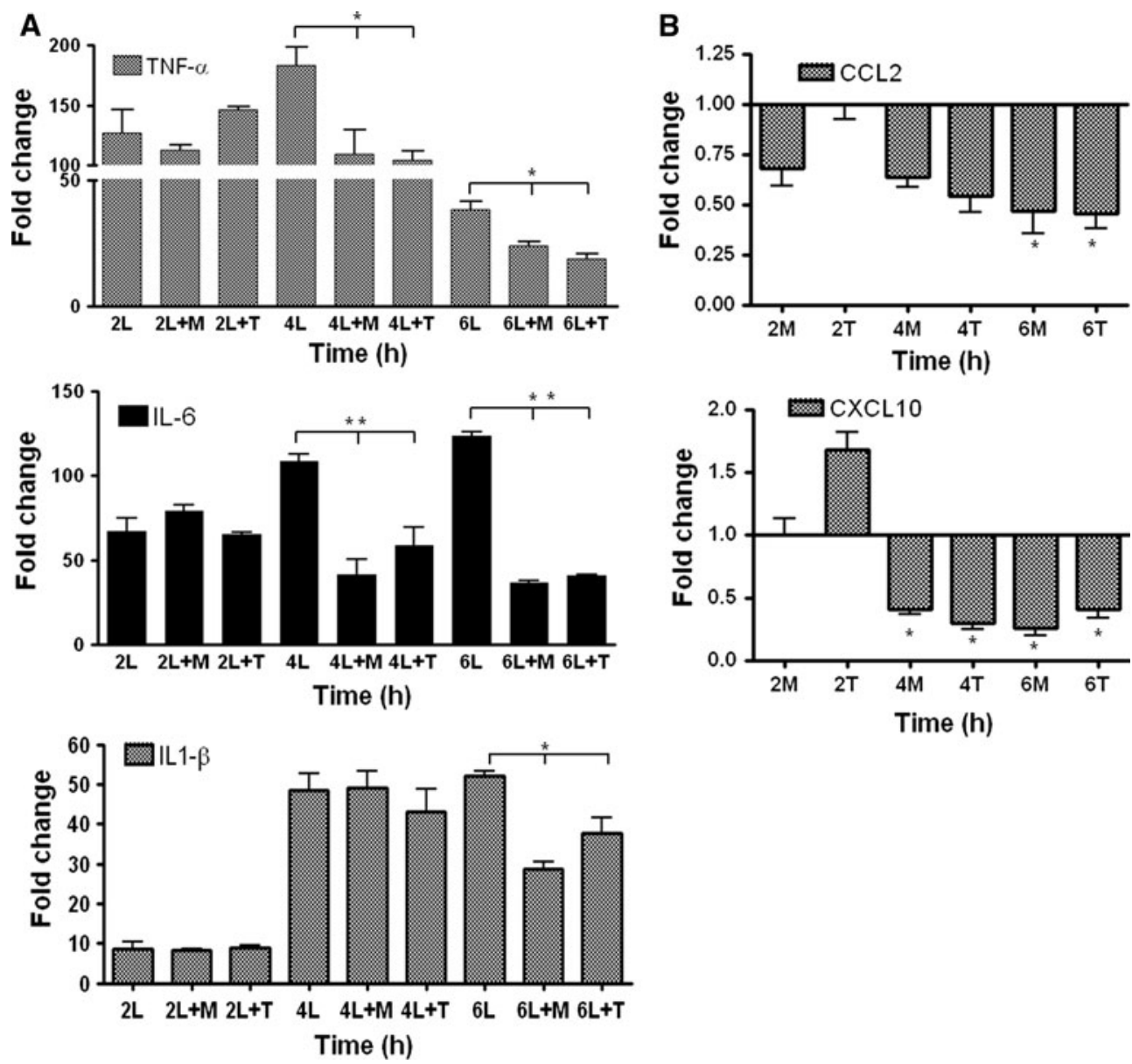

Fig. 10 a RT-PCR analysis of total RNA from rat isolated Kupffer cells treated with LPS in the presence and absence of $\alpha$-MSH and THIQ and $\mathbf{b}$ isolated hepatocytes treated only with $\alpha$-MSH and THIQ. Data shown as fold changes in mRNA expression of TNF- $\alpha$, IL- 6 , IL$1 \beta$, CCL2 and CXCL1 at different time points related to untreated con-

to reduce possible pro-inflammatory consequences of acute-phase cytokines, such as production of chemokines and not the production of anti-inflammatory proteins (e.g., antiprotease).

Recently, a study on mice reported a protective effect of $\alpha$-MSH against experimental multiple organs (including liver) dysfunction syndrome (MODS) by counteracting the systemic inflammatory response. The protective effect is suggested through brain MC4R-triggered activation of the cholinergic anti-inflammatory pathway, which is counteracted and inhibited by the administration of the MC4R antagonist (HS024) (Bitto et al. 2011). However, our data offer a possible alternative or additional explanation by indicating that MC4R plays a more direct role within liver cells.

In conclusion, the presence of MCRs in liver cells strongly suggests their role in liver energy metabolism.

Acknowledgments This research was supported by Dr. Sabine Mihm, Professor at the Department of Gastroenterology and Endocrinology, University Medical Center, Georg-August University Goettingen. trols for each time point. qRT-PCR was normalized by using two housekeeping genes: $\beta$-actin and ubiquitin C. Results represent mean value \pm SEM of three experiments, ${ }^{*} p<0.05$. L LPS, $M \alpha-\mathrm{MSH}$ and $T$ THIQ

We thank Dr. Hassan Dihazi, Associate Professor at the Department of Nephrology and Rheumatology, University Medical Center, GeorgAugust University Goettingen and Dr. Mark Stettner from the Department of Neurology, Heinrich-Heine University Duesseldorf for their scientific advice.

Conflict of interest The authors show no conflict of interest.

Open Access This article is distributed under the terms of the Creative Commons Attribution Noncommercial License which permits any noncommercial use, distribution, and reproduction in any medium, provided the original author(s) and source are credited.

\section{References}

Biebermann H, Krude H, Elsner A, Chubanov V, Gudermann T, Gruters A (2003) Autosomal-dominant mode of inheritance of a melanocortin-4 receptor mutation in a patient with severe earlyonset obesity is due to a dominant-negative effect caused by receptor dimerization. Diabetes 52:2984-2988

Bitto A, Polito F, Altavilla D, Irrera N, Giuliani D, Ottani A, Minutoli L, Spaccapelo L, Galantucci M, Lodi R, Guzzo G, Guarini S, 
Squadrito F (2011) Melanocortins protect against multiple organ dysfunction syndrome in mice. Br J Pharmacol 162:917-928

Butler AA (2006) The melanocortin system and energy balance. Peptides 27:281-290

Caruso C, Durand D, Schioth HB, Rey R, Seilicovich A, Lasaga M (2007) Activation of melanocortin 4 receptors reduces the inflammatory response and prevents apoptosis induced by lipopolysaccharide and interferon-gamma in astrocytes. Endocrinology 148:4918-4926

Cohen SE, Kokkotou E, Biddinger SB, Kondo T, Gebhardt R, Kratzsch J, Mantzoros CS, Kahn CR (2007) High circulating leptin receptors with normal leptin sensitivity in liver-specific insulin receptor knock-out (LIRKO) mice. J Biol Chem 282:23672-23678

Elsner A, Tarnow P, Schaefer M, Ambrugger P, Krude H, Gruters A, Biebermann H (2006) MC4R oligomerizes independently of extracellular cysteine residues. Peptides 27:372-379

Engblom D, Kornfeld JW, Schwake L, Tronche F, Reimann A, Beug H, Hennighausen L, Moriggl R, Schutz G (2007) Direct glucocorticoid receptor-Stat5 interaction in hepatocytes controls body size and maturation-related gene expression. Genes Dev 21:11571162

Faggioni R, Fantuzzi G, Fuller J, Dinarello CA, Feingold KR, Grunfeld C (1998) IL-1 beta mediates leptin induction during inflammation. Am J Physiol 274:R204-R208

Fehlmann M, Carpentier JL, Le CA, Thamm P, Saunders D, Brandenburg D, Orci L, Freychet P (1982) Biochemical and morphological evidence that the insulin receptor is internalized with insulin in hepatocytes. J Cell Biol 93:82-87

Gantz I, Fong TM (2003) The melanocortin system. Am J Physiol Endocrinol Metab 284:E468-E474

Ge F, Zhou S, Hu C, Lobdell H, Berk PD (2010) Insulin- and leptinregulated fatty acid uptake plays a key causal role in hepatic steatosis in mice with intact leptin signaling but not in ob/ob or db/ db mice. Am J Physiol Gastrointest Liver Physiol 299:G855G866

Glund S, Krook A (2008) Role of interleukin-6 signalling in glucose and lipid metabolism. Acta Physiol (Oxf) 192:37-48

Lazar MA (2005) How obesity causes diabetes: not a tall tale. Science 307:373-375

Malik IA, Baumgartner BG, Naz N, Sheikh N, Moriconi F, Ramadori $G$ (2010a) Changes in gene expression of DOR and other thyroid hormone receptors in rat liver during acute-phase response. Cell Tissue Res 342:261-272

Malik IA, Moriconi F, Sheikh N, Naz N, Khan S, Dudas J, Mansuroglu T, Hess CF, Rave-Frank M, Christiansen H, Ramadori G (2010b) Single-dose gamma-irradiation induces up-regulation of chemokine gene expression and recruitment of granulocytes into the portal area but not into other regions of rat hepatic tissue. Am J Pathol 176:1801-1815

Mizock BA (1995) Alterations in carbohydrate metabolism during stress: a review of the literature. Am J Med 98:75-84

Mountjoy KG, Robbins LS, Mortrud MT, Cone RD (1992) The cloning of a family of genes that encode the melanocortin receptors. Science 257:1248-1251

Nonogaki K, Fuller GM, Fuentes NL, Moser AH, Staprans I, Grunfeld C, Feingold KR (1995) Interleukin-6 stimulates hepatic triglyceride secretion in rats. Endocrinology 136:2143-2149

Palmer C, Corpuz T, Guirguis M, O'Toole S, Yan K, Bu Y, Jorgenson J, Talbot M, Loi K, Lloyd A, Zekry A (2010) The effect of obesity on intrahepatic cytokine and chemokine expression in chronic hepatitis C infection. Gut 59:397-404

Picard D, Yamamoto KR (1987) Two signals mediate hormone-dependent nuclear localization of the glucocorticoid receptor. EMBO J 6:3333-3340

Ramadori G, Christ B (1999) Cytokines and the hepatic acute-phase response. Semin Liver Dis 19:141-155

Ramadori G, Moriconi F, Malik I, Dudas J (2008) Physiology and pathophysiology of liver inflammation damage and repair. J Physiol Pharmacol 59(Suppl 1):107-117

Ramadori P, Ahmad G, Ramadori G (2010) Cellular and molecular mechanisms regulating the hepatic erythropoietin expression during acute-phase response: a role for IL-6. Lab Invest 90:13061324

Sartipy P, Loskutoff DJ (2003) Monocyte chemoattractant protein 1 in obesity and insulin resistance. Proc Natl Acad Sci USA 100: $7265-7270$

Sebhat IK, Martin WJ, Ye Z, Barakat K, Mosley RT, Johnston DB, Bakshi R, Palucki B, Weinberg DH, MacNeil T, Kalyani RN, Tang R, Stearns RA, Miller RR, Tamvakopoulos C, Strack AM, McGowan E, Cashen DE, Drisko JE, Hom GJ, Howard AD, MacIntyre DE, Van der Ploeg LH, Patchett AA, Nargund RP (2002) Design and pharmacology of $\mathrm{N}-[(3 \mathrm{R})-1,2,3,4-$ tetrahydroisoquinolinium-3-ylcarbonyl]-(1R)-1-(4-chlorobenzyl)-2-[4-cyclohexyl4-(1H-1,2,4-triazol-1-ylmethyl)piperidin-1-yl]-2-oxoethylamine (1), a potent, selective, melanocortin subtype-4 receptor agonist. J Med Chem 45:4589-4593

Seeley RJ, Yagaloff KA, Fisher SL, Burn P, Thiele TE, van Dijk G, Baskin DG, Schwartz MW (1997) Melanocortin receptors in leptin effects. Nature 390:349

Sell H, Eckel J (2009) Chemotactic cytokines, obesity and type 2 diabetes: in vivo and in vitro evidence for a possible causal correlation? Proc Nutr Soc 68:378-384

Sheikh N, Tron K, Dudas J, Ramadori G (2006) Cytokine-induced neutrophil chemoattractant- 1 is released by the noninjured liver in a rat acute-phase model. Lab Invest 86:800-814

Shimizu H, Inoue K, Mori M (2007) The leptin-dependent and -independent melanocortin signaling system: regulation of feeding and energy expenditure. J Endocrinol 193:1-9

Tao YX (2010) The melanocortin-4 receptor: physiology, pharmacology, and pathophysiology. Endocr Rev 31:506-543

Toda C, Shiuchi T, Lee S, Yamato-Esaki M, Fujino Y, Suzuki A, Okamoto S, Minokoshi Y (2009) Distinct effects of leptin and a melanocortin receptor agonist injected into medial hypothalamic nuclei on glucose uptake in peripheral tissues. Diabetes 58:27572765

van de Wall E, Leshan R, Xu AW, Balthasar N, Coppari R, Liu SM, Jo YH, MacKenzie RG, Allison DB, Dun NJ, Elmquist J, Lowell BB, Barsh GS, de Luca C, Myers MG Jr, Schwartz GJ, Chua SC $\mathrm{Jr}$ (2008) Collective and individual functions of leptin receptor modulated neurons controlling metabolism and ingestion. Endocrinology 149:1773-1785

Vrang N, Kristensen P, Tang-Christensen M, Larsen PJ (2002) Effects of leptin on arcuate pro-opiomelanocortin and cocaine-amphetamine-regulated transcript expression are independent of circulating levels of corticosterone. J Neuroendocrinol 14:880-886

Wallenius V, Wallenius K, Ahren B, Rudling M, Carlsten H, Dickson SL, Ohlsson C, Jansson JO (2002) Interleukin-6-deficient mice develop mature-onset obesity. Nat Med 8:75-79 